\title{
eu me rabisco
}

\author{
TINA ZANI ${ }^{1}$ \\ ...je suis entièrement blanc, \\ je suis d'une grande blancheur. \\ Tarkos
}

eu me rabisco, eu me rabisco toda. me risco, me escrevo, me esboço, me rabisco. eu me desenho. minha mão se move, me contorna, me traceja, eu fico rasurada. estou rabiscada. minha mão me rabiscou. ela me rabisca o tempo todo. minha mão me rabisca sem que eu possa controlar, ela é livre, eu não a controlo, não decido nada, ela é quem decide, ela age sozinha. minha mão me desenha, me esboça o corpo, eu fico desenhada. ela faz o que quer, age sem controle, eu não consigo controlar minha mão, ela é soberana, atua por livre e espontânea vontade, eu não a limito mais eu não a controlo, não consigo controlar. ela me escreve eu me escrevo, fico toda anotada, minha mão me narra, ela me delata sem que eu dê permissão, sem que eu peça, eu não sei mais o que fazer, ela faz o que bem quer, ela pensa que pode fazer o que bem quer e ela faz, eu não tenho querer, eu não a posso limitar, eu perdi o controle. ela me descreve, me desenha em riscos, me rascunha, me preenche com tinta. minha mão me copia sem me perguntar, ela não me pergunta mais, ela vai na frente, está muito à frente. ela decidiu me copiar, me transcreveu, eu estou transcrita, narrada, estou em linhas no papel. meu corpo está desenhado. eu não sei se o que minha mão faz é bom ou ruim, é bonito ou feio, eu não posso saber, eu não consigo decidir, eu não entendo o que ela faz, o que ela quer fazer. eu estou absolutamente capturada, totalmente delineada pontilhada, minha mão me tracejou, ela tem seu próprio querer, tem suas vontades, minha mão está sem controle, totalmente solta. ela não me obedece mais, eu não mando, não consigo mandar, ela decide sozinha, faz o que quer, não me avisa, não me pede permissão, minha mão não conversa sobre o assunto ela não troca ideia comigo, ela age sozinha, age como quer quando quer, ela me desvela. minha mão espalha desenhos sobre meu corpo, ela desenhou no dedinho do meu pé, ela não me respeita

1 Tina Zani é graduada em Artes pela Unicamp e graduanda em Estudos Literários pela mesma universi dade.

mtina.zani@gmail.com 
mais, está livre, gritou independência, não quer mais prestar contas, não me ouve, não me obedece, ela tem seus próprios pensamentos, suas próprias vontades. ela quer desenhar, quer me denunciar, ela me rabisca, me pontua, me expóe inteira, ela se move como bem entende. estou escrita estou esboçada. diga se o que ela faz é bom é belo, diga se entende o que ela faz. eu não sei, eu não sei de nada, eu não a posso controlar, não posso decidir, não consigo, eu não decido. minha mão faz tudo sozinha, ela se move, me rabisca, me risca. eu estou totalmente desenhada eu me desenhei. eu sou uma imensa garatuja. 